\title{
Mas que Hamlet é esse?!
}

\author{
Renata Cazarini de Freitas
}

We remake Shakespeare in our own image to reflect our own concerns and preoccupations. (PETER REYNOLDS)

O texto clássico existe em condição de altruísmo. Ainda que intelectuais queiram e busquem, não raras vezes, manter intocados os textos considerados canônicos, entre eles, por exemplo, os clássicos da Antiguidade e a obra de William Shakespeare, seu status depende da disposição para que se deixem replicar com variações, assegurando, assim, sua permanência no universo cultural. Tomo o termo "variação", aqui, na quarta acepção apresentada no Dicionário Eletrônico Houaiss, que explicita: variação é "cada uma das manifestações possíveis de alguma coisa que oferece alternativas na sua forma, conservando sua natureza intrínseca". Se for aceitável uma analogia com a biologia evolutiva $^{1}$, os clássicos são replicadores de si e as obras que deles "descendem" são seus replicantes². É a transmissão persistente de elementos mínimos caracterizadores, como se marcadores genéticos desses textos, que os define como canônicos; de outra forma, sem sua propagação, eles cairiam no esquecimento ou, para prosseguir com a analogia, seriam virtualmente extintos.

Tal como os seres vivos, os textos clássicos são "survival machines", expressão que pego emprestada de Richard Dawkins, etólogo, autor de The

\footnotetext{
${ }^{1}$ Brian Boyd, autor do capítulo "Making Adaptation Studies Adaptive" no recente The Oxford Handbook of Adaptation Studies (2017), situa a prática da adaptação textual no espectro mais amplo das estratégias adaptativas dos seres vivos e, coincidência, exorta os pesquisadores da área a considerar essa abordagem. 2 Sobre o uso de "replicar" e substantivos derivados, a acepção de "reproduzir" é ancorada na etimologia latina (re+plico) no sentido de "redobrar". Se a frase de Linda Hutcheon (2006, p.173) que concebe a adaptação como "repetition but without replication" tem sido amplamente usada, deve-se observar que a pesquisadora apresenta também a seguinte formulação (ibidem): "replications - like adaptations - are never without variations".
} 
Selfish Gene (1976), que cunhou no citado livro o termo "meme", hoje tão disseminado. Apesar do título de sua obra, o pesquisador identifica, no processo de seleção natural, a ocorrência de um comportamento de altruísmo recíproco em favor da sobrevivência genética, e essa ideia é condizente com o texto clássico e suas variações, quando se observa como cada um dos lados confere energia vital ao outro: ao mesmo tempo em que a obra canônica se deixa tomar como modelo ou, ao menos, como referência para uma variação de si, esta, por sua vez, legitima ou, ao menos, tenta legitimar, no seu momento presente, certos marcadores desse monumentum da cultura.

O funcionamento dessa relação mútua de altruísmo, estabelecida aqui como uma proposição teórica, pode ser apresentado como uma experiência teatral plenamente documentada. A trupe Grupo Careta estreou em 2014 a montagem de um Hamlet numa variação bem brasileira, intitulada Hamelete - O Cordel, autoria de Octávio da Matta e direção de Lívia Simardi. No início de 2017, a peça havia alcançado sua $13^{a}$ temporada, além de ter recebido prêmios, incluindo o de melhor espetáculo no Festival de Teatro Cidade de São Paulo de 2014. A montagem é classificada pela trupe como uma tragicomédia, com duração de módicos 70 minutos, sendo que Hamlet é a mais longa das peças de Shakespeare e sua encenação integral é estimada em mais de quatro horas. Foram mantidos os tradicionais cinco atos do teatro elisabetano, mas há como que um prólogo, chamado "Entrada dos atores", construído em dez estrofes de cinco redondilhas maiores, para o qual chamo a atenção (MATTA, 2016, p.13-14):

\footnotetext{
Uma entrada faço agora,

Pra você que aqui está.

Bem lá do sertão profundo,

Essa história corre mundo,

Eu pude presenciá.
}

As mulheres mais os homens,

Presentes nesse salão, 
Vão testemunhar um fato,

Registrado em cinco ato

De famoso autor bretão.

No reino de Elizabete,

Shakespeare foi o autor

Que deixou lá registrado,

Num momento do passado

Texto de grande valor.

Um repente faço agora

Da história mais contada

E que vai ganhando vida

Toda vez que é dividida,

A cada instante encenada.

Lá vem o Grupo Careta,

Em versão original,

Dividir com essa gente

Uma história diferente

Do texto inicial.

Hamelete, essa peça,

Bem famosa por sinal,

Se passou na Dinamarca,

E deixamos nossa marca

Nessa terra tropical.

Sendo assim, algumas coisa

Nós tentamo, então, mantê,

Escrevendo tudo em verso,

Montamos outro universo 
Que logo vocês vão vê.

Aqui reino é fazenda,

E castelo é casarão,

Príncipe é filho do dono,

E rainha não tem trono,

Rei não tem coroação.

Queremos, dessa maneira,

Conversar com o escritor,

E mostrar, do nosso jeito,

Que versão não é defeito,

É um jeito de louvor.

Aprecie nosso texto,

Junto com nosso respeito,

E reflita, em seguida,

O ser ou não ser da vida,

Bem lá dentro do seu peito.

Os versos em cordel não poderiam ser mais claros, mas dou destaque às estrofes quatro e nove (em itálico) do texto integral publicado, em 2016, pela Giostri, uma das poucas editoras brasileiras que trazem ao mercado a nova dramaturgia brasileira. A quarta estrofe expõe de maneira simples o que foi dito no início deste artigo de forma erudita: é o replicar que dá vida à obra. A nona estrofe defende a "versão" como um louvor ao modelo e uma interlocução com o autor, estabelecendo a relação intertextual.

Importa observar que Hamelete - O Cordel, embora transforme a Dinamarca numa fazenda sertaneja, preserva quase todos os personagens shakespearianos e muitos de seus nomes, além de várias cenas que costumam sofrer apagamento em favor da brevidade, como a aparição do fantasma do pai de Hamlet. Até mesmo a fala de Horácio, o amigo estoico 
do príncipe da Dinamarca, relatando, na cena 1 do primeiro ato, os prodígios que teriam antecedido a morte de Júlio César nos estertores da República em Roma, se mantém no cordel. Um exemplo de transmissão do wit do bardo se encontra na cena 2 do primeiro ato, quando Cláudio, o rei, e Hamlet, seu sobrinho e filho agora, trocam farpas. Veja-se na edição da RSC (2008, p.35), em pentâmetros iâmbicos; na tradução de Lawrence Flores Pereira (2015, p.60), em dodecassílabos; e a versão cordel (2016, p.30), em redondilhas maiores:

\begin{tabular}{|c|c|}
\hline KING & How is it that the clouds still hang on you? \\
\hline HAMLET & Not so, my lord: I am too much i'th'sun. \\
\hline REI & Que nuvens são essas ainda te assombrando? \\
\hline HAMLET & Mas não, senhor, estou bem à sombra do sol. \\
\hline \multirow[t]{2}{*}{ REI } & Por que deixas essa sombra \\
\hline & De tristeza em teu semblante? \\
\hline HAMLET & É apenas proteção \\
\hline
\end{tabular}

Identificar marcadores nessas relações intertextuais é tanto uma experiência prazerosa como um procedimento crucial, argumenta Julie Sanders, autora de Adaptation and Appropriation (2006, p.25): “É a própria resistência e sobrevivência do texto fonte que possibilita o processo continuado de leituras justapostas que são cruciais para as operações culturais de adaptação". ${ }^{3}$ A asserção dessa reciprocidade é fundamental para a compreensão tácita da horizontalidade que prevalece no processo criativo, incluindo traduções e adaptações.

A adaptação criativa, se não é um processo novo, tampouco parece ter sido antes tão disseminada como agora, diante da portentosa indústria

\footnotetext{
3 "It is the very endurance and survival of the source text that enables the ongoing process of juxtaposed readings that are crucial to the cultural operations of adaptation." As traduções do inglês são minhas, exceto quando identificado outro tradutor.
} 
do audiovisual e dos jogos eletrônicos ${ }^{4}$, como atesta exaustivamente Linda Hutcheon em seu livro A Theory of Adaptation (2006). A pesquisadora refuta a hierarquização de textos por precedência ou gênero, isto é, não há por que considerar, por exemplo, um romance no qual se baseie um filme mais acima na hierarquia da produção cultural, mesmo porque, inúmeras vezes, por meio da versão atualizada da obra é que se dá o contato inicial do público com o texto canônico. Para Hutcheon (2006, p.xiii)5: "Múltiplas versões convivem horizontalmente, não verticalmente".

Essa coexistência horizontalizada é um importante pressuposto para a abordagem de certas ocorrências na transmissão de textos clássicos, como a de um replicante atuando como replicador. A situação não é rara e pode ser bem exemplificada com a versão que o poeta inglês Ted Hughes (19301998) fez do poema dramático latino Oedipus (Édipo), de Sêneca (c.4 a. C.-65 d. C.), intelectual de grande projeção no período da dinastia imperial julioclaudiana em Roma, tendo sido preceptor do imperador Nero. O poema dramático inglês The Oedipus of Seneca, de Hughes, foi encenado pela primeira vez em 1968, na Inglaterra, tornando-se o texto icônico da peça latina nos palcos de língua inglesa em todo o mundo.

O replicante funcionou também como replicador no Brasil quando o poema inglês foi o texto de partida, em 1996, para a montagem da peça Édipo de Tabas, tratada como uma adaptação da tragédia senequiana pela companhia Teatro Promíscuo, numa versão tropicalizada, como o título revela na alusão que faz às aldeias indígenas. ${ }^{6}$

Portanto, se há, de um lado, o texto enquanto "adaptação criativa", pode-se, sem dificuldade, identificar sua contraparte como uma "criação adaptativa", uma obra que mostra resiliência no processo de ser adaptada a novos modos de pensamento - diferente mídia, gênero, língua, tempo, cultura - e, claro, carrega a propriedade de preservação de seus elementos mínimos caracterizadores, isto é, marcadores, unidades fundamentais de

\footnotetext{
${ }^{4}$ Especificamente sobre a indústria da adaptação literária para o cinema, ver Simone Murray, The Adaptation Industry: The Cultural Economy of Contemporary Literary Adaptation (2012).

5 "Multiple versions exist laterally not vertically."

${ }^{6}$ Ver, da autora, o artigo "A Glauberiana, um coro trágico de Édipo: do mundo antigo ao Brasil tropical", publicado em Itinerários (Unesp Araraquara), v.45, p.35-51, 2017. Consultado em 07 jul. 2018: https://periodicos.fclar.unesp.br/itinerarios/article/viewFile/9020/7258
} 
hereditariedade. Mantendo ainda a analogia com a biologia evolutiva, Dawkins esclarece como o conceito darwinista de "sobrevivência do mais apto" implica a estabilização da forma a tal ponto que lhe permita ser nomeada e reconhecida (1989, p. 13): “A primeira forma de seleção natural era simplesmente uma seleção de formas estáveis e uma rejeição de formas instáveis". ${ }^{7}$ A estabilidade da forma é condição para que seja replicada.

Sabe-se como a poética, em diferentes períodos da cultura ocidental, valorizou a preceituação genérica, induzindo a criação literária a seguir formas estáveis, portanto, reconhecíveis. ${ }^{8}$ Não se tratava, porém, de produzir réplicas idênticas. A escolha de modelos para emulação nunca teve a ver com a cópia servil. Também na biologia, como observa Dawkins, o procedimento de cópia tende à "imperfeição", mas pode levar erraticamente a melhorias, como se assume que tenha acontecido no processo evolutivo da vida. Por outro lado, acorrem a esse processo errático três fatores de estabilização: longevidade, fecundidade, fidelidade. Textos clássicos são replicadores que tiveram assegurada sua longevidade por meio da transmissão manuscrita e impressa, e que, por meio da reprodução em traduções e adaptações, garantiram sua fecundidade e a "fidelidade" possível, evitando a desfiguração num grau que os tornaria irreconhecíveis.

"Perfeição/imperfeição", "fidelidade" e "evolução" são termos por vezes usados entre aspas e com parcimônia nesta analogia porque destoam do raciocínio que se pretende desenvolver ${ }^{9}$ - observe-se que na evolução natural é aceito o que se chama "erro de cópia" ("erratic copying"), ocorrência que põe em xeque a chamada "fidelidade". Curiosamente, ao desenvolver esse argumento, Dawkins (1989, p.16) faz uma analogia com a tradução da bíblia hebraica para o grego no período helenístico, a Septuaginta, e as

\footnotetext{
7 "The earliest form of natural selection was simply a selection of stable forms and a rejection of unstable ones."

${ }^{8}$ Shakespeare e dramaturgos coetâneos não seguiram o preceito da unida de ação, espaço e tempo. Assim afirma Northrop Frye (2011, p.24): “Felizmente, os dois soberanos reinantes, Elizabeth e Jaime, parecem ter sido razoavelmente liberais em tais questões, e o drama inglês nunca foi limitado por uma camisa de força do modo que o drama francês no tempo de Luís XIV".

${ }^{9}$ Como afirma Christine Geraghty acerca de adaptações de livros para a tela e do tipo de crítica mais frequente sobre esses processos criativos (2008: 3): "Fidelidade importa se importa para o espectador" ("Faithfulness matters if it matters to the viewer."). Esse pressuposto é válido, mas não é um eixo intelectual deste artigo que uma adaptação ou tradução deva ser "fiel".
} 
consequências de enormes proporções da versão do termo hebraico "almah" (mulher jovem) da profecia sobre a chegada do Messias (Isaías 7:14) pelo grego koiné "parthénos" (virgem).

Admitida a tendência à "imperfeição" no processo de replicação do texto clássico, traduções e adaptações, embora se baseiem na semelhança com ele, são variações dele. Se pudermos concordar 1) que os replicadores não são permeáveis à abnegação irrestrita, ou seja, não se deixam simplesmente desaparecer diante da variação; e 2) que aos replicantes não interessa a ação predatória que levaria à extinção o seu referente amplamente reconhecível; fica estabelecida, então, a relação de altruísmo recíproco. Ou seja, é benéfico a Hamelete - O Cordel que seja visto como uma variação do clássico shakespeariano, portanto, o autor evita o apagamento do modelo, promovendo seu reconhecimento pelo público.

Diante disso, refuto o entendimento - ainda muito frequente - da adaptação como parasita do texto clássico ${ }^{10}$, sugerindo, no lugar, como ocorre entre seres vivos, uma relação de mútuo benefício ou simbiótica, perfeitamente compatível com o altruísmo recíproco. Se, na natureza, como alerta Dawkins (1989, p.183), tende a ser difícil distinguir as situações de benefício mútuo daquelas de exploração ou parasitismo, no ambiente da produção cultural, é muito evidente que as variações (os replicantes) compensam os seus modelos (os replicadores) com o que já foi apontado aqui como "fatores de estabilização": longevidade, fecundidade e a chamada "fidelidade".

Minha pesquisa de doutoramento ${ }^{11}$ parte desse conjunto de premissas para a tradução e estudo da fronteira entre a possibilidade de reconhecimento ou não de um modelo e a probabilidade de sua desfiguração no processo de adaptação criativa, tomando como corpora os já citados poemas dramáticos de Sêneca e de Hughes sobre o mito de Édipo.

\footnotetext{
${ }^{10}$ Ver o bem humorado artigo de Thomas Leitch de 2011 "Vampire Adaptation", publicado no Journal of Adaptation in Film \& Performance (vol. 4 № 1).

${ }^{11} \mathrm{O}$ presente trabalho foi realizado com apoio da Coordenação de Aperfeiçoamento de Pessoal de Nível Superior - Brasil (CAPES) - Código de Financiamento 001.
} 
No presente artigo, pretendo fazer uso dessas premissas para analisar muito brevemente se alguns elementos mínimos têm sido mantidos em diferenciadas recentes encenações de Hamlet no Brasil.

É preciso ponderar que a acidentada história de transmissão do texto da peça acaba por sujeitá-lo à dúvida sobre até que ponto ele possa ou deva ser tomado como "definitivo". ${ }^{12}$ Peter Reynolds, autor da frase em epígrafe, contemporiza (1991, p.48) que cada performance deve ser entendida como uma das interpretações possíveis do texto e que nenhuma é definitiva, mas não se subtrai à polêmica e tenta estabelecer uma fronteira entre "interpretação" e "adaptação":

\begin{abstract}
Sendo necessário fazer a distinção entre o que seja interpretar e o que seja adaptar Shakespeare (mesmo que apenas em razão dos ditames de certos questionamentos públicos), então, o limite é a reescritura das falas, apesar de haver evidências consideráveis que indicam que essa era uma prática no teatro elisabetano. [...] Mesmo que não se chegue a reescrever Shakespeare, continua disponível uma gama enorme de interpretações criativas, algumas das quais podem provocar gritos angustiados daqueles que encaram como sua a tarefa de defender a expressão própria de Shakespeare. (REYNOLDS, $1991, \mathrm{p} .48)^{13}$
\end{abstract}

Minha abordagem também pressupõe que um texto dramatúrgico se realiza na encenação, que significados são construídos na performance. Como assinala Reynolds (1991, p.21), ainda que muitos vejam Hamlet como uma peça discursiva, talvez até mesmo verborrágica pelos solilóquios do protagonista, ela é repleta de movimento, incluindo mudanças de plano físico (p.ex., Laerte pulando na cova de Ofélia, na cena 1 do quinto ato), cheia de entradas e saídas de personagens - um palco mais ativo do que o do drama atual.

\footnotetext{
${ }^{12}$ Sobre a transmissão do texto de Hamlet, ver Frye (2011, p.107-108), Reynolds (1991, p.1-4), Pereira (2015, p.41-42), Shakespeare (2008, p.10-12).

13 "If a distinction needs to be made between interpreting and adapting Shakespeare (if only because of the dictates of some public examinations), then it should stop at the rewriting of the spoken text despite the fact that a considerable amount of evidence suggests that this was common Elizabethan playhouse practice. [...] Even if we stop short of rewriting Shakespeare, an enormous range of creative interpretations remain open, some of which may arouse the anguished cries of those who see it as their task to defend Shakespeare's right of self-expression."
} 
Assim, listo apenas montagens a que tive a chance de assistir no intervalo de um ano. ${ }^{14}$

\author{
Hamlet - processo de revelação \\ (dir. Coletivo Irmãos Guimarães) \\ Visto no Sesc Ipiranga, SP (5/3/2017) \\ Estreia: agosto 2015 - DF \\ Hamlet ex-máquina \\ (dir. Érika Bodstein/42 Coletivo Teatral) \\ Visto na Oficina Oswald de Andrade, SP (21/4/2017) \\ Estreia: abril 2017 - SP
}

Dinamarca

(dir. Pedro Wagner/Grupo Magiluth)

Visto no Sesc Belenzinho, SP (8/10/2017)

Estreia: agosto 2017 - PE

Hamlet

(dir. Boris Nikitin)

Visto na MITsp (7/3/2018)

Estreia: setembro 2016 - Basel, Suíça

Hamlet

(dir. Paulo de Moraes/Armazém Cia de Teatro)

Visto na Fundição Progresso, RJ (11/3/2018)

Estreia: junho 2017 - RJ

\title{
Transmissão “memética”
}

\footnotetext{
${ }^{14}$ Hamelete - O Cordel foi vista muito antes desse intervalo. Nesse período, vi ainda "Os vilões de Shakespeare" (direção de Sergio Módena, texto de Steven Berkoff), em que Hamlet é listado como um dos vilões.
} 
Na tarefa de identificar elementos mínimos que tenham sido preservados nos vários Hamlet listados, será utilizado o termo conceito cunhado por Dawkins há mais de 40 anos: o "meme", definido no Dicionário Eletrônico Houaiss como "informação visual ou textual que se espalha pela rede", cuja etimologia é o inglês "meme" a partir do grego "mímēma" ou "cópia". ${ }^{15} \mathrm{O}$ cientista intitulou "Memes: the new replicators" o breve último capítulo do livro de 1976, em que, fazendo uma analogia com o gene, apresenta o "meme" como unidade mínima de transmissão cultural, argumentando em favor do "princípio básico" de que toda vida evolui pela sobrevivência de entes replicadores.

Numa nota adicionada à edição de 1989, o cientista revela como bastou pouco mais de uma década para a propagação do termo criado por ele. Mas isto vem como curiosidade. O que mais interessa é a insistência de Dawkins em que quaisquer replicadores, universalmente, desenvolverão organismos ou máquinas de sobrevivência, também chamados "sistemas complexos" (1989, p.322), ou seja, um sofisticado padrão genético estabilizado ao longo de um processo de associação e combinação particular de marcadores mínimos.

Mas vamos lembrar que se toma aqui o neodarwinismo de Dawkins apenas como uma analogia para o campo de estudos da produção cultural, mais especificamente da transmissão com variação de um texto clássico ou canônico até a atualidade. Assim, em linha com os estudos da adaptação de Robert Stam (2000, p.66), pode-se reconhecer os textos-fonte como redes intrincadas de relações "de textos gerando outros textos num processo infindável de reciclagem, transformação e transmutação, sem um ponto de origem claro". ${ }^{16}$ Mas esse enfoque, de caráter pós-estruturalista, não é consensual, como comprova o questionamento de Thomas Leitch (2017, Kindle 467-468): “Se todos os textos são intertextos, como os estudiosos da

\footnotetext{
15 Não se pode ignorar a acepção corrente do "Internet meme" (Limor Shifman, Memes in digital culture, 2014). Viktor Chagas, coordenador do Museu de Memes da Universidade Federal Fluminense (UFF), afirma: "Memes não são conteúdos individuais e isolados, mas complexos informacionais que só significam em conjunto" em http://www.museudememes.com.br/o-que-sao-memes/, consultado em 10 ago. 2017. O tema também é discutido em http://www.museudememes.com.br/problematizando-o-quee-meme-i-definicoes/, consultado em 10 ago. 2017.

16 "Of texts generating other texts in an endless process of recycling, transformation and transmutation, with no clear point of origin."
} 
adaptação cada vez mais estão inclinados a aceitar, então, que intertextos deveriam ser chamados 'adaptações' e por quê?". ${ }^{17}$

Neste nosso universo particular, diferente da programação cega da máquina de sobrevivência, há o fator do agenciamento: ao menos um agente - ou o tradutor ou o adaptador - consciente da replicação que vai levar a cabo. É muito provável que uma das perguntas que o agente se coloque seja equivalente à proposta por Dawkins a respeito da antiquíssima ideia da existência de um deus (1989, p.193): “Por que ela tem tão elevado índice de sobrevivência?" Para essa pergunta, ele mesmo arrisca uma resposta:

\begin{abstract}
O que realmente está em causa é: - O que há na ideia de um deus que lhe garante estabilidade e inserção no ambiente cultural? $O$ índice de sobrevivência do meme 'deus' no repositório de memes é decorrente do seu grande apelo psicológico. Ele fornece uma resposta superficialmente plausível para as questões profundas e perturbadoras sobre a existência. [...] Deus existe, mesmo que seja apenas na forma de um meme com alto índice de sobrevivência ou poder de contágio no ambiente fornecido pela cultura humana. ${ }^{18}$ (DAWKINS, 1989, p.193)
\end{abstract}

Objetos culturais como a palavra oral e a escrita, a música e as artes visuais são veículos de replicação do meme, mas nem todos têm a mesma taxa de sucesso - claramente. Os fatores de estabilização acima mencionados são tomados por Dawkins como qualidades que levam ao alto índice de sobrevivência de alguns memes, e destaca a relevância maior da fecundidade sobre a longevidade, mas quando trata do fator "fidelidade", o etólogo reconhece que está pisando em ovos (1989, p.194). Para ilustrar esse ponto, Dawkins reporta-se ao procedimento que ele mesmo adota ao replicar no seu livro ideias de outros cientistas. Ele as distorce em benefício de seu próprio argumento, dando diferente ênfase, misturando-as às suas propostas (1989, p.195): “Os memes estão sendo transmitidos a vocês com alterações na

\footnotetext{
17 "If all texts are intertexts, as adaptation scholars have increasingly been inclined to agree, then which intertexts should be called adaptations, and why?"

18 "The question really means: What is it about the idea of a god that gives it its stability and penetrance in the cultural environment? The survival value of the god meme in the meme pool results from its great psychological appeal. It provides a superficially plausible answer to deep and troubling questions about existence. (...) God exists, if only in the form of a meme with high survival value, or infective power, in the environment provided by human culture."
} 
forma" ${ }^{19}$ Mas a analogia entre meme e gene se sustenta, diz ele, porque, em ambos os casos, há que considerar uma "unidade de conveniência", sendo, no caso da seleção natural, uma extensão da cadeia de cromossomos suficiente para que seja identificada como uma cópia. No caso dos memes, o argumento segue assim:

Até agora falei de memes como se fosse óbvio em que consistia uma unidade de meme. Mas é claro que está longe de ser óbvio. Eu disse que uma música é um meme, mas que tal uma sinfonia: quantos memes ela tem? Cada movimento é um meme? Cada frase melódica reconhecível? Cada compasso, cada acorde ou o quê? [...] Se uma única frase da nona sinfonia de Beethoven é suficientemente distinta e memorável para ser abstraída do contexto total da sinfonia e usada como o prefixo de uma emissora europeia irritantemente intrusiva, então, nessa medida, ela merece ser chamada de meme. ${ }^{20}$ (DAWKINS, 1989, p.195)

Portanto, o meme preserva uma "essência", como afirma Dawkins (1989, p.195), que pode ser transmitida de um cérebro a outro (1989, p.196), sendo que as diferenças em torno de uma ideia não fazem parte do meme. Ele afirma ainda que convém que "essências" muito próximas componham um só meme. Adicionalmente, um meme, como um gene, pode ter sido replicado com erro $(1989$, p.323) - um meme que passou por uma mutação, por assim dizer, e sobrevive porque revela algum valor cultural.

Tomo a liberdade de substituir uma exemplificação muito localizada de Dawkins por um equivalente brasileiro: a disseminação dos versos “batatinha quando nasce / se esparrama pelo chão" em substituição ao chamado "original" da quadrinha popular "batatinha quando nasce / deita rama pelo chão". Note-se que ambos são compostos em redondilha maior e veiculam essencialmente a mesma ideia, mas é impossível justificar a prevalência do primeiro sobre o segundo. Na visão do cientista, memes tiram proveito de seu ambiente cultural (DAWKINS, 1989, p.199), tentando

\footnotetext{
19 "The memes are being passed on to you in altered form."

20 "So far I have talked of memes as though it was obvious what a single unit-meme consisted of. But of course it is far from obvious. I have said a tune is one meme, but what about a symphony: how many memes is that? Is each movement one meme, each recognizable phrase of melody, each bar, each chord, or what? (...) If a single phrase of Beethoven's ninth symphony is sufficiently distinctive and memorable to be abstracted from the context of the whole symphony, and used as the call-sign of a maddeningly intrusive European broadcasting station, then to that extent it deserves to be called one meme."
} 
prevalecer sobre outros memes que concorrem no processo de seleção, como se agentes de sua própria preservação.

\title{
Hamlet no Brasil
}

Roberto Ferreira da Rocha, num artigo sobre as encenações de Hamlet no Brasil até a década de 1990, identifica três momentos do processo de modernização do teatro no país e escolhe uma montagem da peça em cada período: Hamlet (1948), com o ator Sérgio Cardoso no papel título, Hamlet (1969), direção de Flávio Rangel, e Ham-let (1993), de Zé Celso, do Oficina. Enquanto o primeiro deles mantinha a aura do "herói problemático do século XIX" (ROCHA, 2016, p.263) na consagrada atuação de Sérgio Cardoso, a montagem com o ator Walmor Chagas se propunha a algo muito diferente, segundo Rangel:

\begin{abstract}
Um clássico não tem ranço e não tem bolor. Um clássico tem algo a dizer a todas as épocas e a todos os homens. Verificar o que Hamlet tem a dizer ao homem contemporâneo, ao homem que vive no Brasil nesta época agitada, foi a nossa tentativa. É claro que achamos que o "príncipe melancólico" morreu em Hiroshima, em 6 de agosto de 1945. Das cinzas, surgiu um novo príncipe; um homem que recebeu uma tarefa acima das suas forças, e que se esforça por cumpri-la. Nós tentamos acompanhá-lo nesta saga. (RANGEL apud ROCHA, 2016, p.264)
\end{abstract}

Como atesta o pesquisador, Walmor Chagas é um "intelectual em crise tentando enfrentar e compreender as mudanças históricas que o atingiam" (ROCHA, 2016, p.265). Já Marcelo Drummond, ator do Oficina, faz-se de "canastrão", combinando trágico e cômico, sublime e grotesco, retrato do nosso processo de redemocratização (ROCHA, 2016, p.265-266).

E, no século XXI, tal qual Horácio se admira diante das revelações de Hamlet sobre os ardis do rei Cláudio - “Mas que rei é esse?" (Ato 5.2.62, trad. Pereira, p.183) -, também eu, no meu assento na plateia: “Mas que Hamlet é esse?!". Denominador comum entre os cinco espetáculos é a linguagem atualizada, evitando as "longas passagens no empolado estilo eufuístico, pontuadas por trocadilhos e mirabolantes figuras de linguagem" (OLIVEIRA, 2008, p.24), características do texto em inglês. 
Na esteira do raciocínio de Dawkins, fazendo uma analogia com a sinfonia, talvez a linguagem shakespeariana como um todo não deva ser tomada como um meme, mas, certamente, o mais famoso verso da dramaturgia ocidental tem que ser.

"To be, or not to be, that is the question" (Ato 3.1.56, trad. Pereira, p.111: "Ser ou não ser: eis a questão") tem sido replicado com mutações. No cordel, tornou-se: "Viver no ser ou não ser? Uma arretada questão!" (MATTA, 2016, p.65). Em Hamlet - Processo de revelação, a formulação mesma da pergunta - seria "this" or "that"? - é colocada em xeque ("Hamlet Processo de Revelação - Palco Giratório", 2017). Também a peça de língua alemã, encenada na Mostra Internacional de Teatro de São Paulo (MITsp), reescreve o verso, apagando a opção marcada pela conjunção "ou" em favor da duplicação: "ser e não ser ao mesmo tempo", como afirma o diretor Boris Nikitin ("Pensamento em Processo sobre o espetáculo Hamlet", 2018). O performer e músico Julian Meding, no papel de Hamlet, diz: “Não ser. Não ter de ser. Não ter de ser eu".

Até mesmo quando a "elaboração da palavra" é um dos critérios da montagem e não se altera de fato o sentido do texto inglês, há razão para a reelaboração em português, como explica a atriz Patrícia Selonk, que faz Hamlet no espetáculo da Armazém Cia de Teatro:

\begin{abstract}
A gente tentou ser o mais fiel possível à história e à elaboração da palavra do Shakespeare, mas é uma versão contemporânea. A gente tentou tratar o Shakespeare como um igual. Como alguém que vive agora, no tempo em que a gente está. [...] Tirando o pó um pouco do Shakespeare, está ele lá, na essência total dele. Por exemplo, "ser ou não ser, eis a questão" é "ser ou não ser, esta é a pergunta". De alguma forma isso mostra a elaboração da palavra, mas mais próximo da galera de hoje. ("Espetáculo Hamlet - Armazém Cia. de Teatro", 2017).
\end{abstract}

Se a personagem que dá título à peça parece - até agora - ser um meme inevitável, um elemento mínimo incontornável na transmissão da obra, todas as outras já se tornaram dispensáveis. Dois dos cinco espetáculos listados são solos, podendo ser classificados como autoficção, um segmento 
que tem sido mais frequente nos palcos e avança também sobre textos clássicos como Hamlet.

O ator e dramaturgo Emanuel Aragão, no solo Hamlet - Processo de revelação, estabelece uma interlocução com o público e aproxima sua identidade à do protagonista da tragédia de Shakespeare. Não há texto fixo. O eixo dramatúrgico é a evocação dos sentimentos pela perda do pai nos dois casos. “A gente vai fazendo um paralelo entre o que ele [Hamlet] poderia sentir e o que eu poderia sentir e, a partir daí, a gente me acessa. Então, a gente tenta se aproximar, usar o meu corpo, a minha capacidade ou a minha incapacidade de articular coisas, pra se aproximar desse cara, desse suposto Hamlet, que a gente inventa a cada dia junto com a plateia" ("Agenda Curta! Peça Hamlet - Processo de Revelação", 2016).

O Hamlet do suíço Nikitin é, abertamente, uma abordagem crítica do teatro documental, recorrendo a uma personagem que já faz, na opinião do diretor, parte da cultura pop, confrontando as expectativas do público num espaço lúdico de associações possíveis com o performer Meding, que explora as potencialidades do corpo não normativo:

\footnotetext{
É uma ilusão de documentário. Então, começamos o processo construindo essa mistura, entre ele, o Hamlet, sempre com referências ao Hamlet, mas também sobre ele. Então, durante os ensaios, é sobre ele, mas também não é sobre ele ao mesmo tempo. Essa é a premissa da peça. É sobre uma identidade potencial. ("Pensamento em Processo sobre o espetáculo Hamlet", 2018).
}

Nada de estranho, me parece, que Hamlet se torne matéria de experimentações teatrais dessa natureza, em linha com o comentário de Frye, quando diz que a peça de Shakespeare "à medida que é um estudo de sua personagem principal, é talvez o exemplo mais impressionante, na literatura, de um espírito titânico que se debate na prisão formada pelo que ele é" (FRYE, 2011, p. 126).

Considerando-se os espetáculos listados, também a música, a dança e o canto são elementos que se incorporaram a esse Hamlet que se quer atualizado, um fator de inserção cultural no altamente performático século XXI. Exceto pelo solo dirigido pelos Irmãos Guimarães, o recurso à música 
contemporânea é um denominador comum às demais montagens, que têm trilha sonora e mesmo performances ao vivo. Em Hamlet ex-máquina, que toma a versão do alemão Heiner Müller como base e avança sobre o texto inglês de Shakespeare, apresentando-se como um espetáculo multilíngue e multicultural, a música bem brasileira é veículo de humor e criatividade. Também nessa linha segue a peça Dinamarca, que encena uma festa durante todo o espetáculo. Na montagem da Armazém Cia de Teatro, a opção musical é o punk.

\section{Desce a cortina}

Ainda muito distante de elencar minuciosamente memes que perpetuem Hamlet, este artigo, embora não tenha o propósito de defender uma leitura de Shakespeare exclusivamente contemporânea a nós, constata que isso acontece o mais das vezes, sendo que o intento evidente dos agentes dessas novas montagens teatrais é o de explicitar a mútua relação com o poeta e dramaturgo inglês.

Entre as justificativas que apresentam para reencenar o texto - bem, às vezes, não se trata propriamente do texto! - parece se destacar, nos dias de hoje, o seu aspecto político. Como diz o diretor Paulo de Moraes, “Hamlet é uma peça extremamente violenta, é um golpe de estado, é uma usurpação", e isso condiz com o Brasil de hoje ("Espetáculo Hamlet - Armazém Cia. de Teatro", 2017). Mas isso não dista muito da visão do diretor europeu Nikitin quando afirma:

\footnotetext{
A peça tem muito a ver com empoderamento e com a criação da identidade, principalmente com relação a esse embate com a realidade, porque ao encarar a realidade e o poder, você entende a necessidade de ser alguém, de ter uma identidade e, ao mesmo tempo, a peça também é sobre não ter que ser alguém, mas poder ser alguém. Para mim, esse é o cerne da peça. ("Pensamento em Processo sobre o espetáculo Hamlet", 2018).
}

Em 1961, o polonês Jan Kott lançou o livro que leva um título que se tornou expressão corrente: "Shakespeare nosso contemporâneo", associando o pessimismo existencialista ao inevitável peso da história decorrente da 
Revolução russa e crimes de Josef Stalin, além das duas guerras mundiais. Luís Fernando Ramos, na "Apresentação" à edição brasileira, afirma:

\begin{abstract}
Mais do que trazer uma nova leitura de Shakespeare, Kott, um crítico de teatro e de cinema vivendo na Polônia socialista e submetida ao jugo soviético, propôs um novo tratamento daquela tradição dramática. Como um encenador que projetasse um olhar para Shakespeare à luz de sua própria realidade, ele estabeleceu uma sincronia entre a perspectiva existencialista e o desencanto de Shakespeare com sua própria época, reordenando o corpo da obra de modo a enfatizar aspectos estruturais e sintetizar, em algumas cenas-chave ou em planos cinematográficos decisivos, um Shakespeare que falasse àquela contemporaneidade. (RAMOS, 2003, p.8)
\end{abstract}

Uma geração depois, apesar das muitas críticas a Kott, a ideia da atualidade de Shakespeare havia se disseminado tanto que Frye decidiu fazer um alerta no livro que publicou em 1986:

\footnotetext{
Mas, se pensarmos em Shakespeare apenas como nosso contemporâneo, perderemos uma das maiores recompensas do estudo das humanidades, que é a investigação das convicções e dos valores das sociedades totalmente diferentes da nossa e a percepção de o que elas fizeram com estes. (FRYE, 2011, p.13)
}

Navegando de lá para cá no espaço e no tempo, Hamlet, a peça, tem atracado nos mais variados portos e desembarcado em territórios que lhe são estranhos e estrangeiros, mas não inóspitos. Nessa odisseia, em muito semelhante ao processo adaptativo da vida, alguns elementos podem ficar pelo caminho, mas a rota de volta ao lar, o nóstos, essa viagem de regresso em busca de um porto seguro, essa não se esquece nunca.

\title{
Referências
}

\section{AGENDA CURTA! Peça "Hamlet - Processo de Revelação".}

Disponível em https://www.youtube.com/watch?v=ce6pyA8riyE. Acesso em: 01 abr 2018. 
BOYD, Brian. "Making Adaptation Studies Adaptive", in: Thomas Leitch, ed. The Oxford Handbook of Adaptation Studies. Oxford University Press. Edição do Kindle, 2017.

CAMATI, Anna Stegh e MIRANDA, Célia Arns de (Orgs). Shakespeare sob múltiplos olhares. Curitiba: Editora UFPR, 2016.

DAWKINS, Richard. The Selfish Gene: New Edition. Oxford: Oxford University Press, 1989 (1976).

ESPETÁCULO “Hamlet": Armazém Cia de Teatro. Reportagem: Danielle Domingo. Produção: Brenda Marques. Imagens: Daniel Moreno. Edição de imagens: Luigi Buzelle. AGENDA, Rede Minas, MG. 5'57'. 2017, video. Disponível em https://www.youtube.com/watch?v=Wq6nn-u2HAw. Acesso em: 01 abr 2018.

FRYE, Northrop. Sobre Shakespeare. Tradução de Simone Lopes de Mello. São Paulo: Edusp, 2011.

GERAGHTY, Christine. Now a Major Motion Picture: Film Adaptations of Literature and Drama. London: Rowman \& Littlefield Publishers, 2008.

HAMLET - Processo de Revelação. Agenda Curta! Canal Curta! Direção: Adriano e Fernando Guimarães. Dramaturgia e elenco: Emanuel Aragão. 2016, video. Disponível em: https://www.youtube.com/watch?v=ce6pyA8riyE. Acesso em: 01 abr 2018.

HAMLET - Processo de Revelação. Palco Giratório 2017. Sesc Rondônia, RO. 1'49". 2017, video. Disponível em https://www.youtube.com/watch?v=gCqK3mwmqbI. Acesso em: 01 abr 2018.

HUTCHEON, Linda. A Theory of Adaptation. New York: Routledge, 2006. KOTT, Jan. Shakespeare nosso contemporâneo. Tradução de Paulo Neves. São Paulo: Cosac \& Naify, 2003 (1961).

LEITCH, T. (Ed). The Oxford Handbook of Adaptation Studies (Oxford Handbooks). Oxford University Press. Edição do Kindle, 2017. . "Vampire adaptation", in: Journal of Adaptation in Film \&

Performance, Vol.4, № 1, p. 5-16. Intellect Ltd., 2011.

MATTA, Octávio da. Hamelete - O Cordel. São Paulo: Giostri, 2016.

OLIVEIRA, Solange Ribeiro de. Hamlet: leituras contemporâneas. Belo Horizonte: Tessitura; CESh, 2008. 
PENSAMENTO em Processo sobre o espetáculo Hamlet. Mostra Internacional de Teatro de São Paulo (MITsp). São Paulo, SP. 54'44". 2018, vídeo. https://www.youtube.com/watch?v=Pv2_WQz6m8s\&t=154s. Acesso em: 01 abr 2018.

PEREIRA, Lawrence Flores. "Nota sobre o texto". In: SHAKESPEARE, W. A tragédia de Hamlet, príncipe da Dinamarca. Tradução de Lawrence Flores Pereira. São Paulo: Penguin Classics Companhia das Letras, 2015. p.41-42. RAMOS, Luís Fernando. "Apresentação". In: KOTT, J. Shakespeare nosso contemporâneo. Tradução de Paulo Neves. São Paulo: Cosac \& Naify, 2003 (1961). p.7-18.

REYNOLDS, Peter. Shakespeare: Text into Performance. London: Penguin Books, 1991.

ROCHA, Roberto Ferreira da. "Hamlet com cara de Brasil: reverenciado, questionado, carnavalizado e deglutido". In: CAMATI, Anna Stegh e MIRANDA, Célia Arns de (Orgs). Shakespeare sob múltiplos olhares. Curitiba: Editora UFPR, 2016. p.261-267.

SANDERS, Julie. Adaptation and Appropriation. New York: Routledge, 2006.

SHAKESPEARE, William. Hamlet. Edited by Jonathan Bate and Eric Rasmussen. Hampshire: The Royal Shakespeare Company, 2008.

A tragédia de Hamlet, príncipe da Dinamarca. Tradução de Lawrence Flores Pereira. São Paulo: Penguin Classics Companhia das Letras, 2015.

STAM, Robert. "Beyond Fidelity: The Dialogics of Adaptation". In: NAREMORE, James (Ed). Film Adaptation. London: Athalone Press, 2000. p.54-76.

\section{Resumo}

O texto clássico existe numa condição de altruísmo recíproco com suas traduções e adaptações. Assumindo uma analogia com a biologia evolutiva, pode-se afirmar que unidades mínimas viáveis de transmissão que constituem um texto clássico, seja da Antiguidade seja da monumental obra de William Shakespeare, os memes, conforme concebidos pelo etólogo 
Richard Dawkins em seu livro The Selfish Gene (1976), como se genes, atuam na transmissão "memética". O texto clássico é, assim, considerado uma "survival machine". Sob essa perspectiva, são abordadas montagens teatrais recentes da peça Hamlet no Brasil.

Palavras-chave: Adaptação; tradução; transmissão; meme; Shakespeare

\begin{abstract}
The classical text exists under the condition of reciprocal altruism in relation with its translations and adaptations. In an analogy to the evolutionary biology, it can be said that the viable minimal units of transmission in a classical text, whether from Antiquity or from the monumental work of William Shakespeare, the memes, created by ethologist Richard Dawkins in his book The Selfish Gene (1976), as if genes, perform the "memetic" transmission. Thus the classical text can be taken as a "survival machine". From this perspective, I assess multiple different Hamlet recently staged in Brazil.
\end{abstract}

Keywords: Adaptation; translation; transmission; meme; Shakespeare 